\title{
Amentoflavone and Kaempferol Glycosides from the Aerial Parts of Cissampelos pareira
}

\author{
Hari Prasad Devkota*, Sena Miyazaki, Shoji Yahara \\ School of Pharmacy, Kumamoto University, Kumamoto 862-0973, Japan
}

\begin{abstract}
Aerial parts of Cissampelos pareira L. (Family: Menispermaceae), commonly known as "Batulpate" in Nepal, are used for the treatment of fever, indigestion and to stop bleeding after child birth. In this study, a biflavonoid, amentoflavone; and two kaempferol glycosides, kaempferol 3-O- $\beta$-D-glucopyranoside and kaempferol 3-O- $\beta$ D-glucuronopyranoside were isolated from $70 \% \mathrm{MeOH}$ extract of the aerial parts. Structures of these compounds were elucidated on the basis of ${ }^{1} \mathrm{H}$ - and ${ }^{13} \mathrm{C}-\mathrm{NMR}$ spectral data. To the best of our knowledge, it is the first report on the isolation of these compounds from a plant belonging to family Menispermaceae.

Keywords: Cissampelos pareira; Menispermaceae; Batulpate; Flavonoids; Amentoflavone

*Corresponding Author

Email: devkotah@kumamoto-u.ac.jp
\end{abstract}

\section{Introduction}

Cissampelos pareira L. (Family: Menispermaceae), commonly known as "Batulpate" in Nepal, is a climbing herb with perennial root-stock. It is distributed throughout Nepal to about $3000 \mathrm{~m}$ altitude. The aerial parts and roots are widely used as traditional medicines in various ailments. The juice of the plant is administered orally to stop bleeding after child birth and to counteract the loss of blood. It is also used as tonic, diuretic and for the treatment of fever and indigestion. The juice is also applied locally to treat skin diseases and the decoction is used to relieve the pain of dislocated bones. The roots are used for the treatment of indigestion, constipation, cough and cold and applied locally in snake bite [1].

Previous studies have reported antiviral [2], antiprotozoal [3] and antifertility [4] activities of the extracts of aerial parts of C. pareira. Regarding chemical constituents, alkaloids are reported as major constituents in leaves [5] and roots [6-10]. Ramirez et al. [3] reported a chalcone-flavone dimer, cissampeloflavone as an antiprotozoal agent from the aerial parts and Ganguly et al. [4] also reported the presence of flavonoids in the leaves of C. pareira. However, there are no other reports about individual flavonoids present in C. pareira aerial parts. Thus, in present study, we focused on the phenolic constituents in the aerial parts and isolated one biflavonoid [1] and two flavonoid glycosides [2, 3], which are reported in this paper.

\section{Materials and Methods} General Experimental Procedures

Optical rotations were measured with a JASCO DIP-1000KUY polarimeter. ${ }^{1} \mathrm{H}-,{ }^{13} \mathrm{C}-\mathrm{Nuclear}$ nuclear magnetic resonance (NMR) spectra were measured on a JEOL $\alpha-500$ spectrometer. Chemical shifts are given in ppm with reference to tetramethyl silane (TMS). Column chromatography was carried out with MCI gel CHP20P (75 $150 \mu \mathrm{m}$, Mitsubishi Chemical Industries Co. Ltd., Tokyo, Japan), Sephadex LH-20 (Amersham Pharmacia Biotech, Tokyo, Japan) and silica gel 60 (0.040-0.063 mm, Merck KGaA, Darmstadt, Germany). Thin layer chromatography (TLC) was performed on a precoated silica gel 60 F254 (Aluminum sheet, Merck KGaA, Darmstadt, Germany) and 10\% sulfuric acid spray followed by heating was used for derivatization.

\section{Plant Material}

Fresh aerial parts of $C$. pareira were collected on June 2010, from Lumle, Kaski District, Nepal and shade dried for two weeks. A voucher specimen has been deposited at Graduate School of Pharmaceutical Sciences, Kumamoto University, Kumamoto, Japan.

\section{Extraction and Isolation}

The shade dried aerial parts (58.0 g) were extracted with $70 \%$ methanol $(\mathrm{MeOH})(1.5 \mathrm{~L} \times 2$ times) at room temperature and the combined extracts were evaporated under reduced pressure to obtain dried 


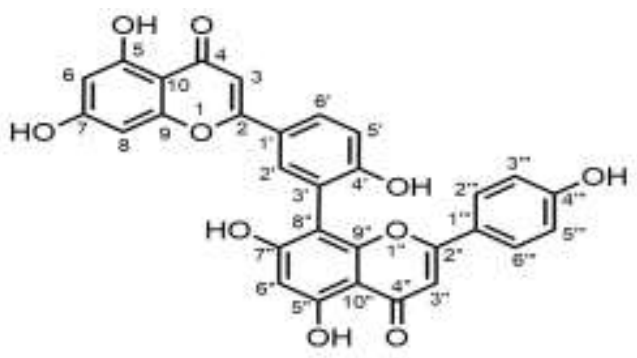

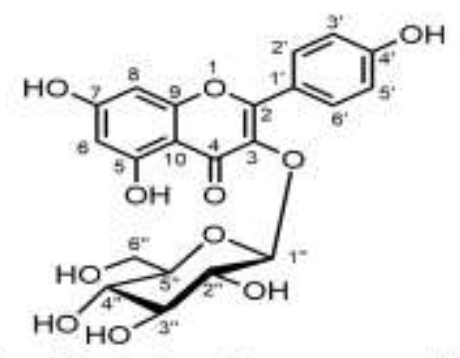

Kaempferol 3-O- $\beta$-D-glucopyranoside (2)

Figure 1: Structures of the isolated compounds

Table 1: ${ }^{1} \mathrm{H}$ - and ${ }^{13} \mathrm{C}-\mathrm{NMR}$ data of compound $\mathbf{1}$ in DMSO-

\begin{tabular}{|c|c|c|c|c|c|}
\hline $\begin{array}{c}\text { C } \\
\text { No }\end{array}$ & $\delta \mathrm{C}$ & $\begin{array}{l}\delta_{\mathrm{H},} \text { mult. } \\
(J \text { in } \mathrm{Hz})\end{array}$ & C No. & $\delta \mathrm{C}$ & $\begin{array}{l}\delta \mathrm{H}, \text { mult. } \\
(J \text { in } \mathrm{Hz})\end{array}$ \\
\hline 2 & $163.9 *$ & & $2 "$ & $\begin{array}{c}163.7 \\
*\end{array}$ & \\
\hline 3 & 102.5 & $6.82, \mathrm{~s}$ & $3 "$ & 102.4 & $6.77, \mathrm{~s}$ \\
\hline 4 & 181.6 & & 4" & 182.0 & \\
\hline 5 & 161.3 & & $5 "$ & 160.4 & \\
\hline 6 & 98.8 & $\begin{array}{c}6.18, \mathrm{~d} \\
(2.1)\end{array}$ & $6 "$ & 98.7 & $6.36, \mathrm{~s}$ \\
\hline 7 & $163.5^{*}$ & & 7" & 161.4 & \\
\hline 8 & 93.8 & $\begin{array}{c}6.44, \mathrm{~d} \\
(2.1)\end{array}$ & $8 "$ & 103.9 & \\
\hline 9 & 157.2 & & $9 "$ & 154.6 & \\
\hline 10 & 103.9 & & $10 "$ & 103.9 & \\
\hline $1^{\prime}$ & 121.2 & & $1 "$ & 121.2 & \\
\hline $2^{\prime}$ & 127.6 & $\begin{array}{c}8.02, \mathrm{~d} \\
(2.4)\end{array}$ & $2 "$ & 128.0 & $\begin{array}{c}7.58, \mathrm{~d} \\
(8.8)\end{array}$ \\
\hline 3 ' & 121.2 & & $3 " '$ & 115.7 & $\begin{array}{c}6.70, \mathrm{~d} \\
(8.8)\end{array}$ \\
\hline $4^{\prime}$ & 159.5 & & 4"' & 160.4 & \\
\hline $5^{\prime}$ & 116.1 & $\begin{array}{c}7.12, \mathrm{~d} \\
(8.5)\end{array}$ & $5 "$ & 115.7 & $\begin{array}{c}6.70, \mathrm{~d} \\
(8.8)\end{array}$ \\
\hline 6 ' & 131.2 & $\begin{array}{l}7.99, \mathrm{dd} \\
(2.4,8.5)\end{array}$ & $6 "$ & 128.0 & $\begin{array}{c}7.58, \mathrm{~d} \\
(8.8)\end{array}$ \\
\hline
\end{tabular}

extract $(10.0 \mathrm{~g})$. The extract was then suspended in water and separated into water soluble and

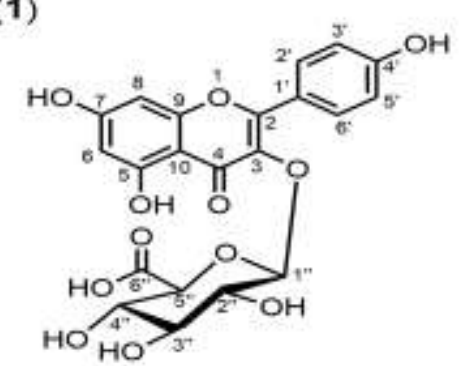

Kaempferol 3-O- $\beta$-o-glucuronopyranoside (3) insoluble fractions. The water soluble fraction (7.9 g) was subjected to $\mathrm{MCI}$ gel CHP20P column chromatography (CC) and eluted successively with water, $40 \%, 70 \%$ and $100 \% \mathrm{MeOH}$ to obtain total 8 fractions (Fr. 1 8). A flavonoid rich fraction, Fr. 6 (200 mg, 70\% MeOH eluate) was subjected to Sephadex LH-20 CC (MeOH) to obtain 5 subtractions (Subfr. 6-1 6-5). Subfractions 6-3 and 6-4 were combined $(30 \mathrm{mg}$ ) and subjected to silica gel $\mathrm{CC}\left(\mathrm{CHCl}_{3}: \mathrm{MeOH}: \mathrm{H}_{2} \mathrm{O}=8: 2: 0.1\right)$ to obtain kaempferol 3-O- $\beta$-D-glucopyranoside; compound 2 $(5.0 \mathrm{mg})$ and kaempferol 3-O- $\beta$-Dglucuronopyranoside; compound $3(2.0 \mathrm{mg})$. The water insoluble fraction $(2.1 \mathrm{~g})$ was subjected to Sephadex LH-20 CC (MeOH) to obtain 8 fractions (Fr. I1 I8). Among them, Fr. I7 (74 mg) was subjected to silica gel $\mathrm{CC}\left(\mathrm{CHCl}_{3}: \mathrm{MeOH}=20: 1\right)$ to obtain amentoflavone; compound $\mathbf{1}$ (2.4 mg).

\section{Amentoflavone (1)}

A pale yellow amorphous powder; ${ }^{1} \mathrm{H}$ - and ${ }^{13} \mathrm{C}$ NMR (in DMSO- $\left.d_{6}\right)$, Table 1.

Kaempferol 3-O- $\beta$-D-glucopyranoside (2) A pale yellow amorphous powder; $[\alpha]_{\mathrm{D}^{20}}-35.8^{\circ}(\mathrm{c}$ 0.75 , pyridine); ${ }^{1} \mathrm{H}$ - and ${ }^{13} \mathrm{C}-\mathrm{NMR}$ (in $\mathrm{CD}_{3} \mathrm{OD}+\mathrm{D}_{2} \mathrm{O}$ ) Table 2.

\section{Kaempferol 3-O- $\beta$-D- glucuronopyranoside} (3)

A pale yellow amorphous powder; $[\alpha]_{D^{20}}-51.2^{\circ}(c$ 
0.52 , pyridine: water $=1: 1$ ); ${ }^{1} \mathrm{H}$ - and ${ }^{13} \mathrm{C}-\mathrm{NMR}$ (in DMSO- $\left.d_{6}\right)$, Table 2.

Table 2: ${ }^{1} \mathrm{H}$ - and ${ }^{13} \mathrm{C}$-NMR data of compounds 2 and 3

\begin{tabular}{|c|c|c|c|c|}
\hline \multirow[t]{2}{*}{ C No. } & \multicolumn{2}{|c|}{$2\left(\right.$ in $\left.\mathrm{CD}_{3} \mathrm{OD}+\mathrm{D}_{2} \mathrm{O}\right)$} & \multicolumn{2}{|c|}{3 (in DMSO- $d_{6}$ ) } \\
\hline & $\delta \mathrm{C}$ & $\begin{array}{l}\delta_{\mathrm{H},} \text { mult. } \\
(J \text { in } \mathrm{Hz})\end{array}$ & $\delta_{\mathrm{C}}$ & $\begin{array}{l}\delta_{\mathrm{H}, \text { mult. }} \\
(\mathrm{J} \text { in } \mathrm{Hz})\end{array}$ \\
\hline 1 & & & & \\
\hline 2 & 157.0 & & 156.2 & \\
\hline 3 & 135.1 & & 133.0 & \\
\hline 4 & 179.0 & & 177.3 & \\
\hline 5 & 161.6 & & 161.0 & \\
\hline 6 & 100.0 & $6.26, \mathrm{~d}(1.8)$ & 98.6 & $6.02, \mathrm{~d}(1.8)$ \\
\hline 7 & 164.6 & & 164.7 & \\
\hline 8 & 95.3 & $6.40, \mathrm{~d}(1.8)$ & 93.8 & $6.22, \mathrm{~d}(1.8)$ \\
\hline 9 & 159.2 & & 156.3 & \\
\hline 10 & 105.6 & & 103.5 & \\
\hline $1^{\prime}$ & 122.6 & & 121.0 & \\
\hline $2^{\prime}, 6^{\prime}$ & 132.0 & 7.97, d (8.5) & 130.9 & $8.00, \mathrm{~d}(8.5)$ \\
\hline $3^{\prime}, 5^{\prime}$ & 116.2 & $6.96, \mathrm{~d}(8.5)$ & 115.0 & $6.83, \mathrm{~d}(8.5)$ \\
\hline $4^{\prime}$ & 160.2 & & 160.0 & \\
\hline $1^{\prime \prime}$ & 103.7 & $5.02, \mathrm{~d}(6.7)$ & 100.8 & $5.53, \mathrm{~d}(7.6)$ \\
\hline $2^{\prime \prime}$ & 74.9 & $3.17-3.90$ & 74.1 & $3.30-3.80$ \\
\hline $3^{\prime \prime}$ & 77.4 & $3.17-3.90$ & 75.4 & $3.30-3.80$ \\
\hline $4^{\prime \prime}$ & 70.5 & $3.17-3.90$ & 72.1 & $3.30-3.80$ \\
\hline $5^{\prime \prime}$ & 77.0 & $3.17-3.90$ & 76.4 & $3.30-3.80$ \\
\hline $6^{\prime \prime}$ & 61.8 & $3.17-3.90$ & 172.2 & \\
\hline
\end{tabular}

\section{Results and Discussion}

In this study, the aerial parts of C. pareira, traditionally used for the treatment of various disorders in folk medicine were investigated for their chemical constituents. Three compounds (1-3) were isolated from the $70 \% \mathrm{MeOH}$ extract by repeated column chromatography on $\mathrm{MCI}$ gel CHP20P, Sephadex LH20 and silica gel. The structures of these compounds were identified as amentoflavone [11], kaempferol 3-O- $\beta$-Dglucopyranoside [12] and kaempferol 3-O- $\beta$-Dglucuronopyranoside [13] (Figure 1) on the basis of NMR spectral data and comparison with reported values in literatures.
To the best of our knowledge, it is the first report on the isolation of these compounds from a plant belonging to family Menispermaceae. Flavonoids and biflavonoid are one of the most widely studied chemical classes of natural products for their distribution in plant families, chemical diversity and various heath beneficial effects. Amentoflavone has been isolated and identified from more than 120 plant species and reported to have several pharmacological effects including potent antioxidant and anti-inflammatory activities [14]. Similarly, kaempferol and/or its glycosides were also reported from more than 400 plant species and showed potent antioxidant, anti-inflammatory, antitumor and antimicrobial activities [15].

In conclusion, three compounds, amentoflavone [1], kaempferol 3-O- $\beta$-D-glucopyranoside [2] and kaempferol 3-O- $\beta$-D-glucuronopyranoside [3] were isolated from the aerial parts of $C$. pareira. These compounds can be utilized as chemotaxonomic markers for the identification of crude drugs based on the aerial parts of $C$. pareira. Further studies are needed to find the possible relationship between these constituents and traditional uses and reported bioactivities of the extracts.

\section{References}

1. Manandhar N P: Plants and People of Nepal. Timber Press, Inc., Portland, 2002 154-155.

2. Sood R, Raut R, Tyagi P, Pareek PK, Barman TK, Singhal S, Shirumalla RK, Kanoje V, Subbarayan R, Rajerethinam R, Sharma N, Kanaujia A, Shukla G, Gupta YK, Katiyar CK, Bhatnagar PK, Upadhyay DJ, Swaminathan S, Khanna N: Cissampelos pareira Linn: natural source of potent antiviral activity against all four dengue virus serotypes. PLoS Negl Trop Dis. 2015 9: e0004255.

3. Ramirez I, Carabot A, Melendez P, Carmona J, Jimenez M, Patel AV, Crabb TA, Blunden G, Cary PD, Croft SL, Costa M: Cissampeloflavone, a chalcone-flavone dimer from Cisssampelos pareira. Phytochemistry. 2003 64: 645-647.

4. Ganguly M, Kr.Borthakur M, Devi N, Mahanta R: Antifertility activity of the methanolic leaf extract of Cissampelos pareira in female albino mice. J Ethnopharmacol. 2007 
111: 688-691.

5. Chowdhury AR: Chemical investigations on Cissampelos pareira. Sci Cult. 1972 38: 358-359.

6. Kupchan SM, Patel AC, Fujita E: Tumor inhibitors VI: Cissampareine, new cytotoxic alkaloid from Cissampelos pareira. Cytotoxicity of bisbenzylisoquinoline alkaloids. J Pharm Sci. 1965 54: 580-583.

7. Morita H, Matsumoto K, Takeya K, Itokawa $\mathrm{H}$, Iitaka $\mathrm{Y}$ : A novel antileukemic tropoloisoquinoline alkaloid, pareirubine, from Cissampelos pareira. Chem Lett. 1993339.

8. Morita $\mathrm{H}$, Matsumoto $\mathrm{K}$, Takeya K, Itokawa $\mathrm{H}$ : Azafluoranthene alkaloids from Cissampelos pareira. Chem Pharm Bull. 1993 41:1307-1308.

9. Morita H, Matsumoto K, Takeya K, Itokawa H, Iitaka Y: Structures and solid state tautomeric forms of two novel antileukemic tropoloisoquinoline alkaloids, pareirubrines A and B, from Cissampelos pareira. Chem Pharm Bull. 1993 41: 1418-1422.

10. Morita $\mathrm{H}$, Matsumoto K, Takeya K, Itokawa $\mathrm{H}$ : Conformation of tropolone ring in antileukemic tropoloisoquinoline alkaloids. Chem Pharm Bull. 1993 41:1478-1480.

11. Terashima K, Kondo Y, Aqil M, Waziri M, Niwa M: A study of biflavanones from the stems of Garcinia kola (Guttiferae). Heterocycles. 1999 50:283-290.

12. Markham KR, Chari VM: Carbon-13 NMR Spectroscopy of Flavonoids, eds. by Horborne JB, Mabry TJ and Mabry H: The Flavonoids Advances in Research. Chapman and Hall, New York, 1982 19-132.

13. Price KR, Colquhoun IJ, Barnes KA, Rhodes MJC: Composition and content of flavonol glycosides in green beans and their fate during processing. J Agric Food Chem. 1998 46:4898-4903.

14. Yu S, Yan H, Zhang L, Shan M, Chen P, Ding A, Li SFY: A Review on the phytochemistry, pharmacology, and pharmacokinetics of amentoflavone, a naturally-occurring biflavonoid. Molecules. 2017 22:299.

15. Calderón-Montaño JM, Burgos-Morón E, Pérez-Guerrero C, López-Lázaro M: A review on the dietary flavonoid kaempferol. Mini Rev Med Chem. 2011 11:298-344. 